\title{
High speed photography - possibilities and barriers
}

\author{
This paper gives an overview of modern high speed photography. The systems that are used at the Institut fuer Kolben- \\ maschinen (IFKM) in Karlsruhe/Germany are described. Two examples for engine application outline the possibilities \\ and challenges in connection with high speed measurements.
}

Key words: optical investigations, high speed photography

\section{Szybkie filmowanie - możliwości i ograniczenia}

\begin{abstract}
Artykut zawiera przeglad nowoczesnych metod szybkiego filmowania. Opisano systemy tego rodzaju wykorzystywane w Instytucie Silników Tłokowych (IFKM) w Karlsruhe (Niemcy). Przytoczono dwa przykłady zastosowania szybkiego filmowania w badaniach silników spalinowych, które wykazuja możliwości i trudności w zastosowaniu takiej techniki badawczej.
\end{abstract}

Słowa kluczowe: badania optyczne, szybkie filmowanie

\section{Introduction}

Today high speed systems have become a well established tool in research and development of combustion engines. All classical areas of optical investigations (spray, flow and combustion) can be covered with systems with a high temporal resolution. Starting with fundamental investigations on spray propagation in pressure chambers and engines over characterization of flame propagation (chemiluminescence and UV-range with intensified cameras) to analyses of the air flow in the combustion chamber (HS-PIV) there is a wide range of possible applications. Furthermore the detection and description of fast combustion phenomena like irregular combustion and knocking is feasible with high speed imaging techniques even in production type engines.

\section{A brief review in history}

One of the first investigations at the Institut fuer Kolbenmaschinen (IFKM) that was performed with a high speed

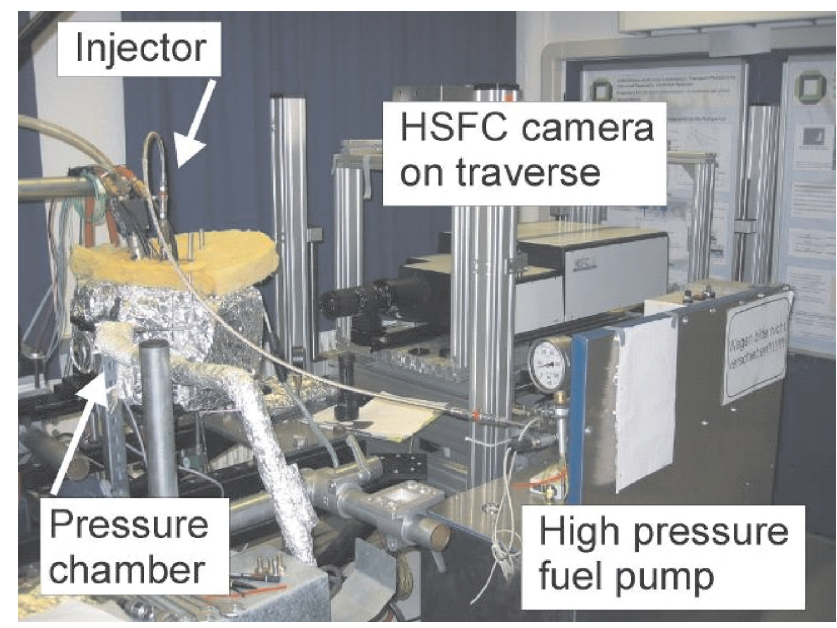

Fig. 1. Experimental set up for the visualization in pressure chamber Rys. 1. System badawczy wizualizacji wtrysku paliwa w komorze ciśnieniowej

\section{Wprowadzenie}

Współczesne systemy szybkiego filmowania stały się uznanym narzędziem w badaniach i rozwoju silników spalinowych. Możliwe jest ich stosowanie w całym tradycyjnym zakresie optycznych badań silnikowych (rozpylana struga, przepływ i spalanie) z zachowanie dużej rozdzielczości czasowej. Zakres jej możliwych zastosowań jest szeroki, począwszy od podstawowych badań rozprzestrzeniania się wtryskiwanej strugi w komorach ciśnieniowych i w silnikach, poprzez opis rozprzestrzeniania się płomienia (chemiluminescencja i zakres promieniowania ultrafioletowego UV z wykorzystaniem wzmacniaczy obrazu), aż do analizy przepływu powietrza w komorze spalania (HS-PIV). Ponadto możliwe jest wykrycie i opis zjawisk szybkiego spalania, jak np. spalanie nieregularne lub stukowe, nawet w wersjach produkcyjnych silników spalinowych.

\section{Krótki przegląd historyczny}

Jedno z pierwszych badań przeprowadzonych w Instytucie Silników Tłokowych (IFKM) z wykorzystaniem szybkiego filmowania odbyło się w 2004 r. Wówczas analizowano interakcję pomiędzy strugą wtryskiwanego paliwa a ścianką komory ciśnieniowej. System badawczy pokazano na rys. 1 .

Rejestrację obrazów prowadzono z wykorzystaniem urządzenia HSFC Pro camera firmy PCO. Ta kamera fizycznie zbudowana jest $\mathrm{z}$ czterech indywidualnych kamer ze wzmacniaczem obrazu pracujących w trybie podziału matrycy CCD (ang.: Charge-Coupled Device), lecz posiada tylko jedno wejście optyczne. Czas pomiędzy kolejnymi zdjęciami ograniczony jest do $2 \mu \mathrm{s}$. Dzięki tej kamerze możliwe było uzyskanie 8 zdjęć w czasie trwania pojedynczego wtrysku paliwa. Rys. 2 pokazuje przebieg oddziaływania strugi na ściankę.

Współcześnie ten typ kamery używany jest rzadko, gdyż ma zbyt duże wymiary, jednak ciągle jeszcze wykazuje pew- 
camera was done in 2004. In this study the interaction of fuel sprays with a wall was analyzed in a pressure chamber. Figure 1 shows the experimental set up.

The image detection was done with a HSFC Pro camera from PCO. This camera physically consists out of four individual intensified double frame CCD cameras but has only one optical input. The interframing time is limited to 2 $\mu \mathrm{s}$. With this camera it was possible to obtain 8 images out of one injection. Figure 2 shows results from the interaction process.

Today this type of camera is only used seldom because of its big dimension but it still has its advantages. The high optical resolution of the images in combination with low interframing times is still very attractive.

\section{High speed systems at IFKM}

\subsection{High speed photomultiplier camera}

For combustion visualization a high speed photomultiplier system is used (Smetec Imaging System). Combustion radiation in UV-and visible wavelength range is collected via an endoscope which consists out of 10,000 optical fibers. The endoscope leads the signals to a photomultiplier camera with 1,920 photomultipliers. The system can be operated with acquisition frequencies up to $200 \mathrm{kHz}$ which for example allows a crank-angle based resolution of 0.1 degree crank angle at an engine speed of 3,000 rpm. With this temporal resolution, up to 100 consecutive cycles can be recorded. Figure 3 shows the visualization system. A detailed technical description of the measurement system and its components can be found in [1].

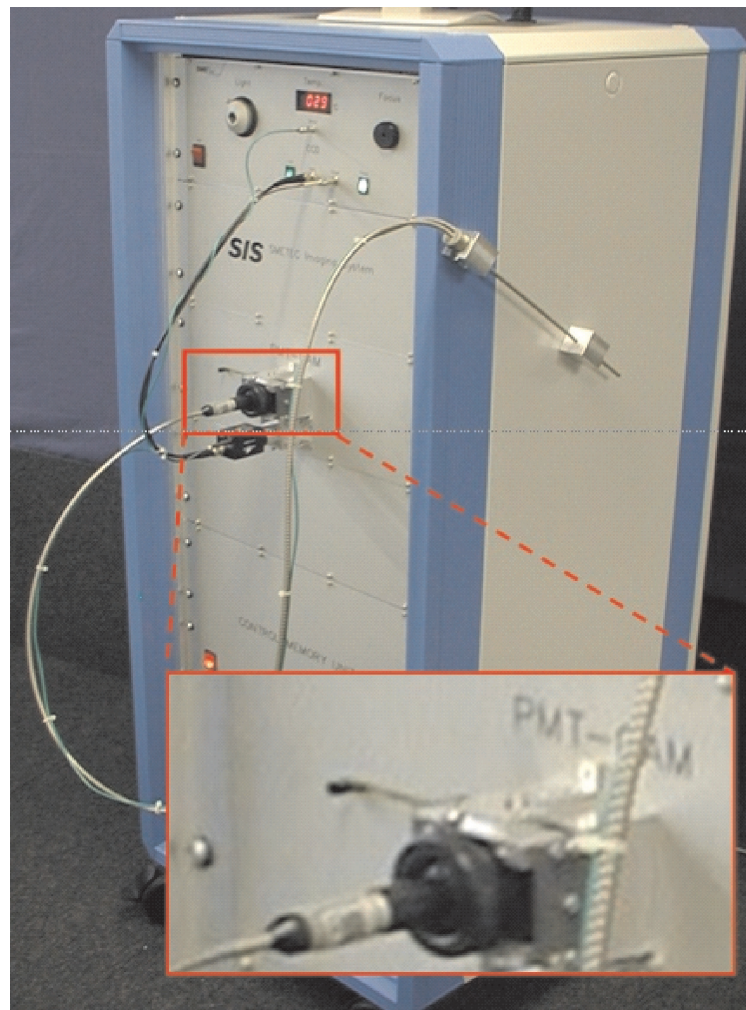

Fig. 3. High speed photomultiplier camera Rys. 3. Kamera z szybkim fotopowielaczem ne zalety. Główną jej zaletą jest duża rozdzielczość optyczna w połączeniu z dużą częstotliwością filmowania.
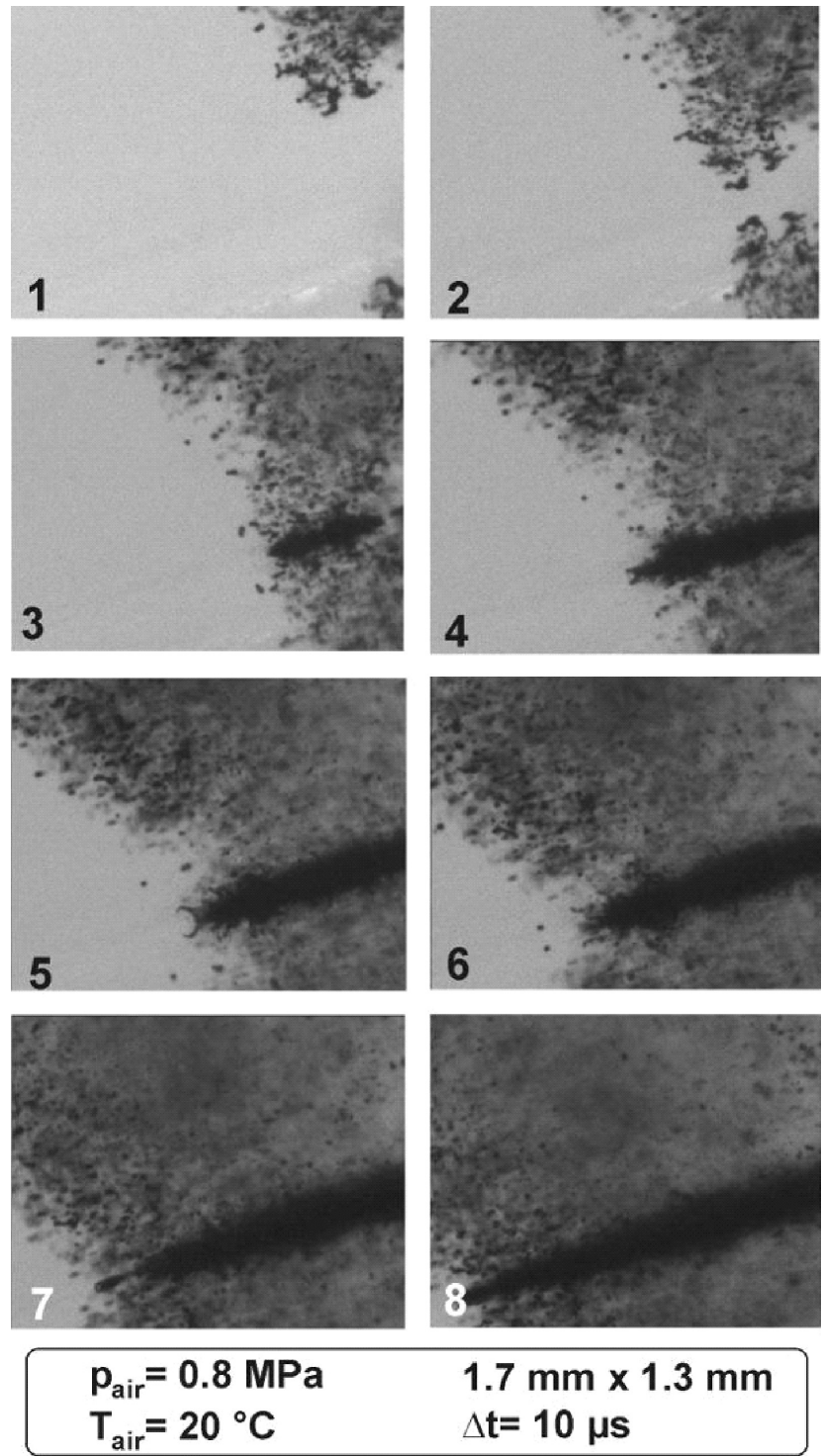

$1.7 \mathrm{~mm} \times 1.3 \mathrm{~mm}$ $\Delta \mathrm{t}=10 \mu \mathrm{s}$

Fig. 2. Sequence of images from one interaction process

Rys. 2. Sekwencja zdjęć z pojedynczego procesu uderzenia strugi paliwa na ściankę cylindra

\section{Systemy szybkiego filmowania $w$ instytucie silników tłokowych}

\subsection{Kamera z szybkim fotopowielaczem}

Do obserwacji spalania używany jest system fotopowielacza dużej szybkości (Smetec Imaging System). Promieniowanie płomienia w zakresie długości fal widzialnych i w ultrafiolecie jest rejestrowany przez endoskop, który złożony jest z 10000 włókien szklanych. Endoskop przekazuje sygnały do kamery zawierającej 1920 fotopowielaczy. System może pracować z częstotliwością rejestracji do 200 $\mathrm{kHz}$, która pozwala na uzyskanie kątowej rozdzielczości $0,1^{\circ}$ OWK przy prędkości obrotowej silnika 3000 obr/min. Przy tej rozdzielczości czasowej można rejestrować do 100 następujących po sobie cykli roboczych. System ten pokazano na 
A simultaneous usage of three individual photomultiplier cameras allows the three-dimensional detection of flame propagation in the combustion chamber. The method is briefly described in [2]. Figure 4 shows an exemplary result for a three-dimensional measurement with photomultiplier cameras.

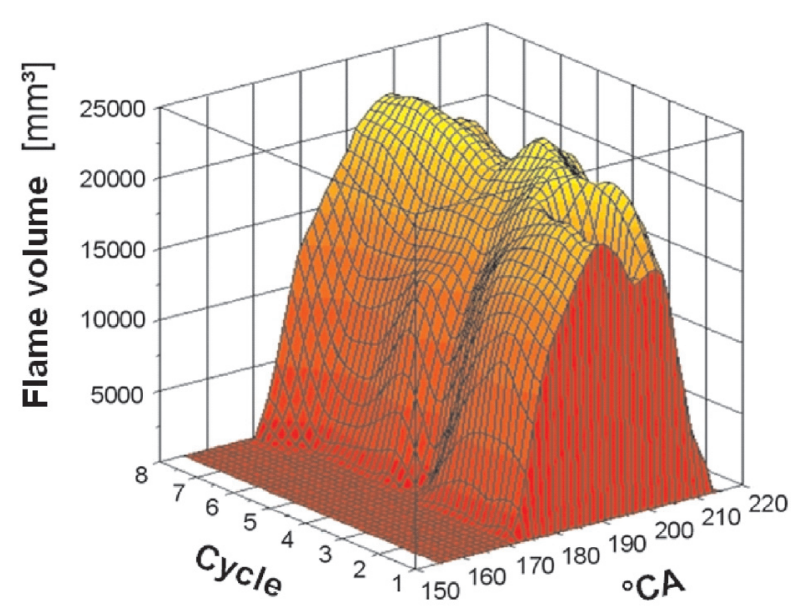

Fig. 4. Development of flame volume over ${ }^{\circ} \mathrm{CA}$ for 8 consecutive engine cycles

Rys. 4: Zmiany objętości ptomienia w zależności od kąta OWK dla 8 następujacych po sobie cykli roboczych silnika

\subsection{High speed CMOS camera}

The second image based high speed system that is used at IFKM is a CMOS camera HSS6 from LaVision. The camera can be used for investigations in the visible range of wavelength or with an optional intensifier in the UV-range. Due to its handy dimensions, the camera is very flexible in adaption under test bed conditions. Figure 5 shows the camera in an application at a single cylinder engine for endoscopic detection of spray propagation.

\section{Example 1. Detection of soot luminescence in a large engine}

Strict emission regulations and the need of higher efficiency of future diesel engines require an optimized combustion process. For getting a better understanding of the combustion process optical investigations represent a powerful tool and they are already widely used within the development process of passenger car and truck engines. For medium speed diesel engines however, optical investigations are still not common due to costs of optical test engines and technical practicability.

Within the IP-Hercules ß project MAN Diesel SE in cooperation with IFKM realized optical in-situ investigations of the combustion process on an MAN Diesel SE 32/44 CR single cylinder medium speed diesel engine (displacement $35 \mathrm{dm}^{3}$ ). For the optical investigations a special optical cylinder head was developed with several optical accesses for endoscopes. Endoscopic investigations were chosen because an emphasis was placed on minimum modifications to the combustion chamber. The deflection of spray and combustion due to the optical instrumentation had to be minimized in rys. 3. Szczegółowy opis techniczny systemu pomiarowego i jego elementów zawiera praca [1].

Jednoczesne stosowanie trzech pojedynczych fotopowielaczy pozwala na trójwymiarowe badanie rozprzestrzeniania się płomienia w komorze spalania. Ta metoda została krótko opisana w pracy [2]. Rys. 4 pokazuje przykładowy wynik pomiarów trójwymiarowych kamerą z fotopowielaczem.

\subsection{Szybka kamera typu CMOS}

Drugim rodzajem systemu szybkiego filmowania używanym w IFKM jest kamera HSS6 typu CMOS (ang. Complementary Metal Oxide Semiconductor) firmy LaVision. Kamera może być stosowana w badaniach dla widzialnego zakresu promieniowania a $\mathrm{z}$ opcjonalnym wzmacniaczem promieniowania - w zakresie promieniowania ultrafioletowego. Ze względu na swoje poręczne wymiary kamera jest wygodna do przystosowania do warunków badań stanowiskowych. Rys. 5 pokazuje taką kamerę zastosowaną w silniku jednocylindrowym dla endoskopowych badań rozprzestrzeniania się strugi wtryskiwanego paliwa.

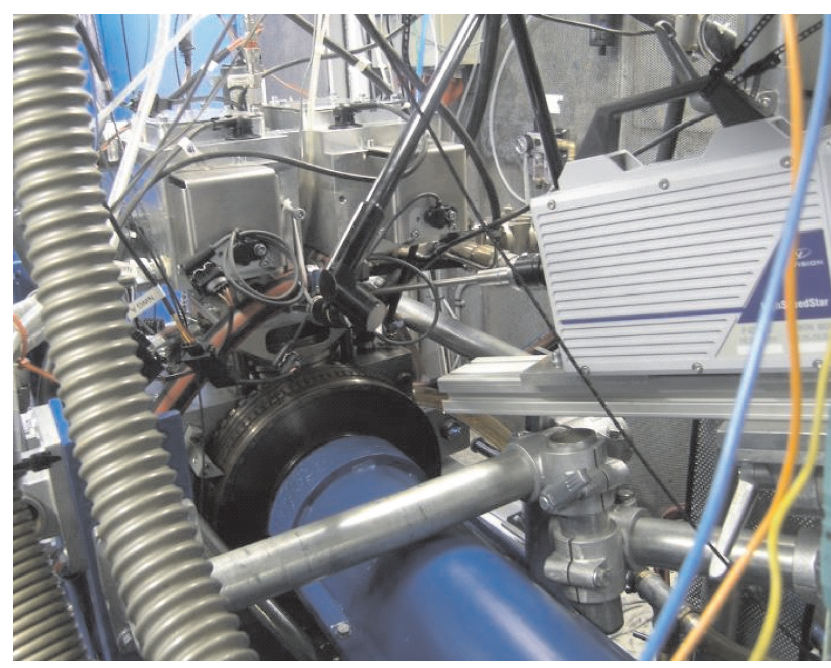

Fig. 5. CMOS camera mounted at the engine Rys. 5. Kamera typu CMOS zamontowana na silniku

\section{Przykład 1. badanie emisyjności sadzy w dużym silniku}

Spełnienie ostrych przepisów emisyjności i potrzeba zwiększenia sprawności przyszłościowych silników ZS wymagają optymalizacji procesu spalania. Dla lepszego zrozumienia procesu spalania bardzo efektywnie służą badania optyczne, które są już szeroko wykorzystywane w rozwoju silników do samochodów osobowych i ciężarowych. W przypadku średnioobrotowych silników ZS badania takie nie są powszechne ze względu na koszty takiej wielkości silnika optycznego i technicznych możliwości.

W ramach projektu IP-Hercules $ß$ silników MAN Diesel SE we współpracy z IFKM zrealizowano badania optyczne procesu spalania w jednocylindrowym silniku średnioobrotowym ZS typu MAN Diesel SE 32/44 CR (pojemność skokowa $35 \mathrm{dm}^{3}$ ). Dla realizacji badań optycznych zastosowano specjalną głowicę z dostępem optycznym przez kilka endoskopów. Do badań wybrano technikę endoskopową po- 
order to obtain results fully representative for the standard engine as well.

\section{Standard 12-hole injector}

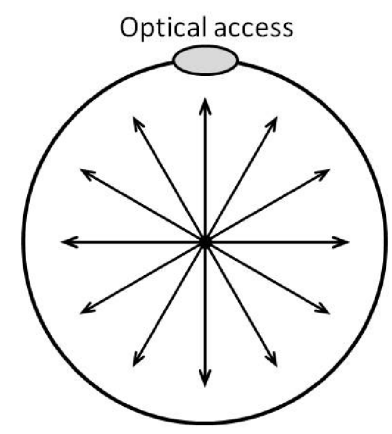

Combustion Chamber 6-hole injector for optical investigations

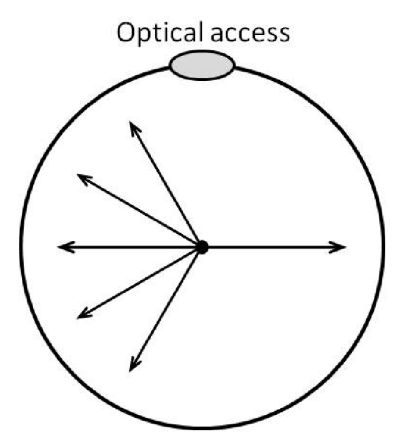

Combustion Chamber
Fig. 6. Standard injector and special injector for optical investigations with reduced amount of nozzle holes

Rys. 6. Wtryskiwacz standardowy i wtryskiwacz specjalny do badań optycznych ze zmniejszona liczba otworków w rozpylaczu

The optical investigations aimed on soot luminescence. For that purpose special injectors were designed for separating a single flame plume and spray cone respectively (see Fig. 6). Pressure and temperature conditions at start of injection were adjusted by modified charge air conditions. Different marine fuels were used for the tests. The images of the combustion process were recorded with an endoscope and a high speed camera (HSS6). Endoscope and camera were directly mounted on the engine (see Fig. 7).

Figure 8 shows an example of the flame propagation with Marine Gas Oil (MGO) for full load conditions at top dead center.

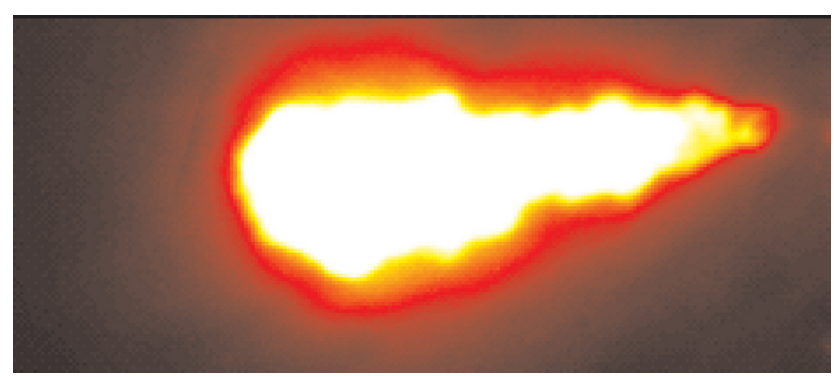

Fig. 8. Example of flame propagation for a full load engine operation point with MGO at top dead center

Rys. 8. Przyktad rozprzestrzeniania się płomienia przy petnym obciązeniu silnika zasilanego paliwem MGO (zdjęcie wykonane w GMP)

For comparing optical images and CFD combustion simulation results, selected engine operating points were simulated with a modified version of the CFD code KIVA3VRelease 2 containing additional sub-models developed both at the Engine Research Center of the University of Wisconsin - Madison (ERC) and at MAN Diesel. The purpose of the comparison was to validate the CFD models with in-situ measurements inside the combustion chamber. nieważ położono nacisk na jak najmniejsze zmiany kształtu komory spalania. Dążono do jak najmniejszego zniekształcenia strugi wtryskiwanego paliwa i przebiegu spalania $\mathrm{w}$ celu uzyskania wyników całkowicie reprezentatywnych dla silnika standardowego.

Badania optyczne koncentrują się na promieniowaniu sadzy. Dlatego do celów badawczych skonstruowano specjalne wtryskiwacze pozwalające na odpowiednie rozdzielenie pojedynczego obłoku płomienia i rdzenia strugi paliwa (por. rys. 6). Ciśnienie i temperatura na początku wtrysku paliwa były ustawiane przez zmianę parametrów powietrza dolotowego. W czasie testów stosowano różne paliwa morskie.

Zdjęcia procesu spalania wykonywano kamerą do szybkiego filmowania (HSS6) przez endoskop. Zarówno kamera, jak i endoskop były zamontowane bezpośrednio na silniku (rys. 7).

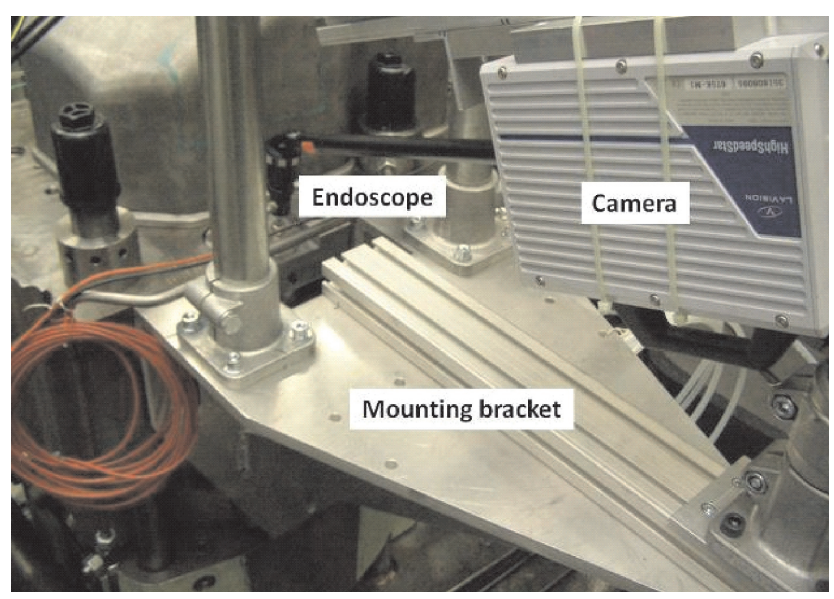

Fig. 7. Endoscope and camera mounting on test engine Rys. 7. Kamera i endoskop zamontowane na silniku

Na rysunku 8 pokazano przykład rozprzestrzeniania się płomienia dla paliwa MGO (Marine Gas Oil) w GMP dla pełnego obciążenia silnika.

Dla porównania wyników badań optycznych z wynikami symulacji typu CFD wykonano obliczenia dla wybranych punktów pracy silnika z wykorzystaniem zmodyfikowanej wersji programu CFD typu KIVA3V-Release2 zawierającego dodatkowe podmodele opracowane w Centrum Badań Silnikowych na Universytecie Wisconsin Madison (ERC) oraz w ośrodku MAN Diesel. Celem tego porównania było skalibrowanie modeli CFD na podstawie rzeczywistych pomiarów wewnątrz komory spalania.

Pierwsze wyniki pokazują, że badania endoskopowe procesu spalania bezpośrednio w komorze spalania mogą dostarczyć odpowiednich danych do walidacji symulacyjnych modeli spalania typu CFD. Użyte modele CFD umożliwiają dla średnioobrotowych silników spalinowych ZS przewidywanie standardowych wyników pomiarów (średnich w cylindrze, przyp. tłumacza), jak np. ciśnienia w cylindrze, szybkości wywiązywania ciepła i emisji $\mathrm{NO}_{x}$, bez wcześniejszej kalibracji parametrów modelu. Porównanie wyników przestrzennych pokazuje, że modele typu CFD umożliwiają wyznaczenie ważnych trendów, jednak nie są 
First results show that endoscopic in-situ investigations of the combustion process can give feasible data for validating CFD combustion simulation models. The used CFDmodels are capable of predicting standard measurement data of medium speed diesel engines like cylinder pressure, heat release rate or $\mathrm{NO}_{\mathrm{x}}$ emissions without adjustment of model parameters. The comparisons of spatially resolved data show that the used CFD models are capable of predicting important trends, but that they are not yet accurate enough for getting exact agreement with the optical images (see Figure 9). Nevertheless, the observed deviations between spatially resolved details represent valuable information about how to further optimize the CFD models with a focus on medium speed diesel engines. Detailed information about the optical measurements and the simulation activities can be found in [3].

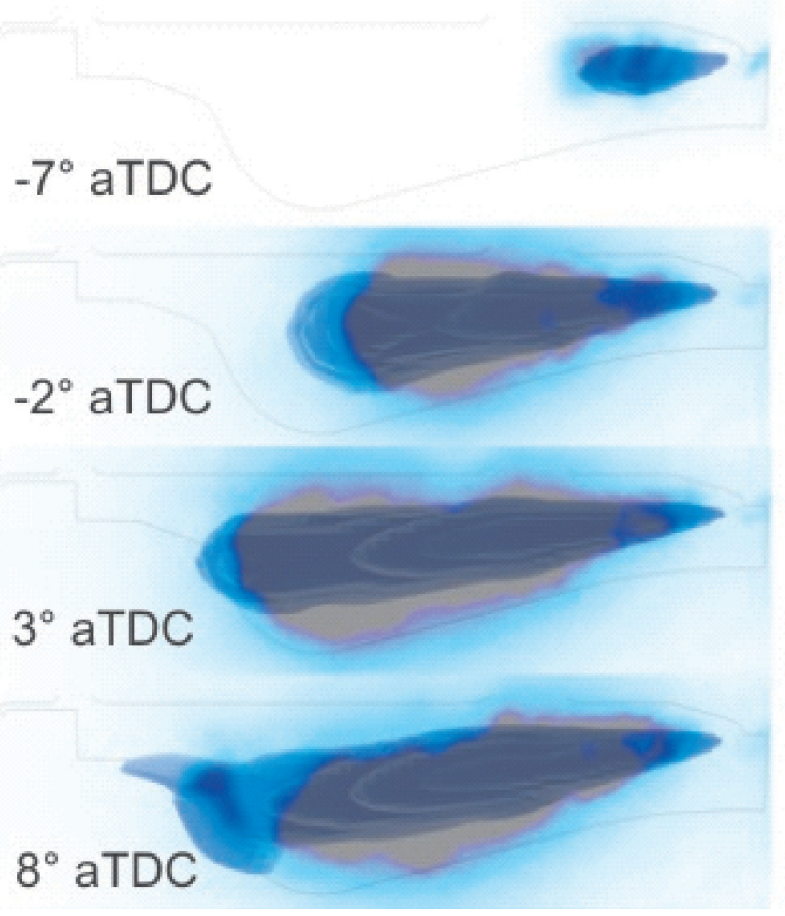

wystarczająco dokładne dla dużej zgodności z obserwacjami optycznymi (rys. 9).

Jednakże stwierdzone rozbieżności pomiędzy wynikami przestrzennymi dostarczają przydatnych informacji dotyczących wymagań dalszej optymalizacji modeli CFD odnoszących się do średnioobrotowych silników ZS. Szczegółowa informacja dotycząca badań optycznych i symulacyjnych zawarta jest w pracy [3].

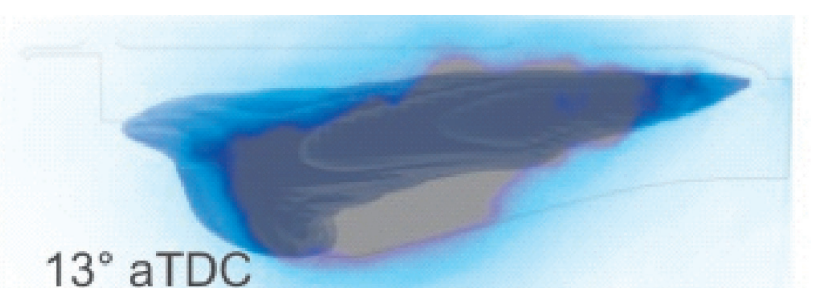

$13^{\circ}$ aTDC
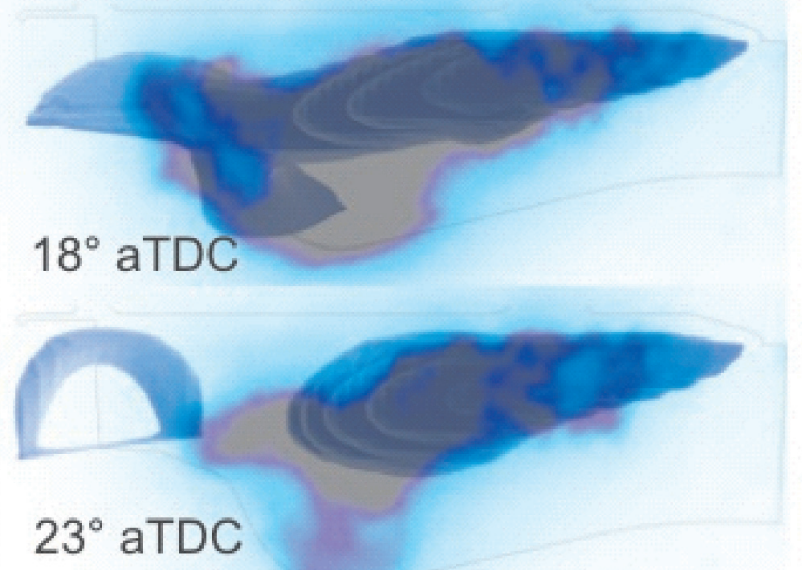

$28^{\circ}$ aTDC

Fig. 9. Overlapped comparison of measurement (black surface) and simulated iso-surface for luminosity (blue surface) for a "simulated" full load engine operation point with MGO

Rys. 9. Porównawcze nałożenie wyników pomiarów (czarna powierzchnia) i symulacji (izo-powierzchnie) promieniowania dla „,symulowanego" petnego obciązenia silnika zasilanego paliwem $M G O$

\section{Example 2. Ignition in a small two stroke engine}

Basically small two-stroke SI engines make high demands on the measurement equipment. The available volume to adapt components is extremely limited because of the engine size. Engine speeds up to $15,000 \mathrm{rpm}$ require high sampling rates and short response times of the measurement techniques to reach a sufficient resolution. In the following, exemplary results of measurements in small two-stroke engines are presented. More details and the application of additional measurement techniques can be found in [4] and [5].

\section{Przykład 2. zapłon w małym silniku dwusuwowym}

Zasadniczo małe dwusuwowe silniki ZI stawiają duże wymagania odnośnie wyposażenia pomiarowego. Ze względu na małe wymiary silnika dostępne miejsce dla zastosowania elementów pomiarowych jest ekstremalnie małe. Prędkości obrotowe silników do $15000 \mathrm{obr} / \mathrm{min}$ wymagają dużych szybkości próbkowania oraz krótkiego czasu reakcji urządzeń pomiarowych dla osiągnięcia wystarczająco dużej rozdzielczości. Dalej przedstawiono przykładowe wyniki pomiarów wykonanych w małym silniku dwusuwowym. Więcej szczegółów oraz informacji dotyczących techniki pomiarowej zawierają prace [4] i [5]. 
Investigations of ignition process and flame propagation have been performed using the high speed photomultiplier cameras described above. As mentioned before, with this systems combustion light signals are detected via fiberoptic endoscopes and the maximum sampling rate is $200 \mathrm{kHz}$. In the application described below two of these systems were used. Figure 10 shows the adaption of the endoscopes via cover at the combustion chamber and the complete engine in the test-stand rack. Figure 11 shows the fields of view for both endoscopes.

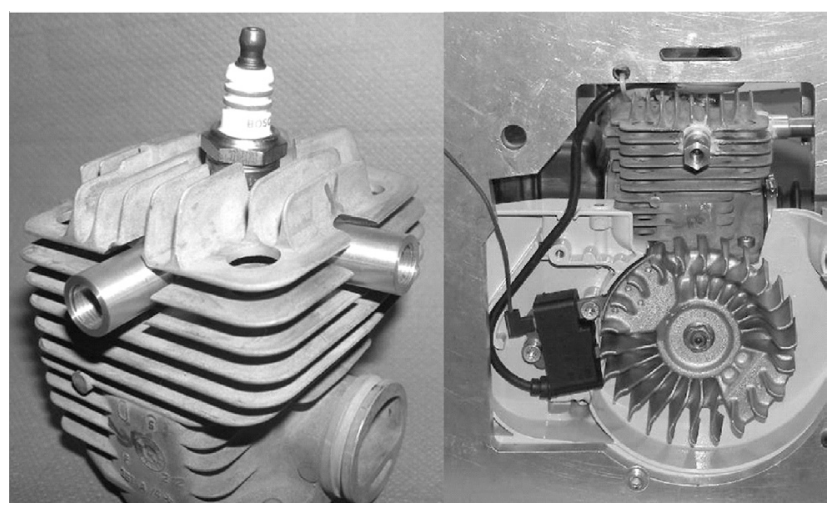

Fig. 10. Adaption of the endoscope mountings Rys. 10. Sposób umieszczenia endoskopów

Endoscope 1 is adapted on the fan side parallel to the crankshaft. The line of vision of Endoscope 2 is oriented in direction of the exhaust, perpendicular to that from the intake. From both observation windows the spark plug can be seen.

The following exemplary measurements have been recorded at full load and a speed of 9,500 rpm. Figure 12 shows the images for $27^{\circ}$ and $11^{\circ} \mathrm{CA}$ before TDC. For better understanding, the position of the spark plug is drawn schematically. At $27^{\circ} \mathrm{CA}$ before TDC the ignition spark in both endoscopes can be seen. The center of the ignition plasma is in each case marked by a crosshairs. At $11{ }^{\circ} \mathrm{CA}$ before TDC the actual combustion began. The center of combustion moved towards the exhaust in Endoscope 1. It can be seen that the scavenging guide resulting from the counter-flow scavenging, is still conserved up to this time.
Badania zapłonu i rozprzestrzeniania się płomienia były przeprowadzone przy użyciu szybkich kamer fotopowielaczowych opisanych powyżej. Jak wcześniej wspomniano, ten system umożliwia rejestrację promieniowania świetlnego płomienia poprzez endoskopy z włóknem szklanym, z maksymalną częstotliwością próbkowania $200 \mathrm{kHz}$. W przypadku opisanym poniżej zastosowano dwa takie systemy. Na rys. 10 pokazano sposób umieszczenia endoskopu przez płaszcz komory spalania i kompletny silnik na stanowisku badawczym. Rys. 11 pokazuje obszary obserwacji przez oba endoskopy.

Endoskop 1 jest montowany po stronie wentylatora równolegle do wału korbowego. Oś obserwacji endoskopu 2 jest zorientowana w kierunku wylotu spalin, prostopadle do osi dolotu. Świeca zapłonowa jest widoczna z obu okien obserwacyjnych.

Przykładowe pomiary przeprowadzono na pełnym obciążeniu silnika przy prędkości obrotowej $9500 \mathrm{obr} / \mathrm{min}$. Na rys. 12 pokazano zdjęcia dla $27^{\circ} \mathrm{i} 11^{\circ} \mathrm{OWK}$ przed GMP. Dla lepszego zrozumienia, schematycznie zaznaczono położenie świecy zapłonowej.

Przy kącie $27^{\circ} \mathrm{OWK}$ przed GMP iskrę zapłonową można zaobserwować przez oba endoskopy. Jądro plazmy zapłonowej na każdym zdjęciu zostało zaznaczone przeciętymi osiami. Przy kącie $11^{\circ} \mathrm{OWK}$ przed GMP rozpoczyna się rzeczywiste spalanie. Centrum płomienia przemieszcza się w kierunku wylotu wg endoskopu 1. Można zaobserwować, że kierunek przepłukania wynikający z przepłukania zwrotnego utrzymuje się do tego czasu. W oknie obserwacyjnym drugiego endoskopu widać wyraźne przemieszczenie tego centrum.

Inna metoda analizy jest pokazana na rys. 13. Pomiary te przeprowadzono przy obciążeniu częściowym i prędkości obrotowej $7000 \mathrm{obr} / \mathrm{min}$. Zdjęcia po lewej stronie pokazują sytuację dla kąta $3^{\circ} \mathrm{OWK}$ przed zapłonem, natomiast zdjęcia po prawej stronie pokazują chwilę zapłonu. Można łatwo zauważyć, że płomień powstaje przed zapłonem. Ten samozapłon powstaje na gorącym fragmencie komory spalania pomiędzy elektrodą a wylotem spalin. To zjawisko nie może być wykryte przez pomiar ciśnienia w cylindrze, ponieważ chwila samozapłonu następuje bardzo krótko przed zapłonem rzeczywistym. Powodem samozapłonu jest prawdopodobnie bardzo duży udział spalin resztowych. Taka mieszanka jest łatwo za-

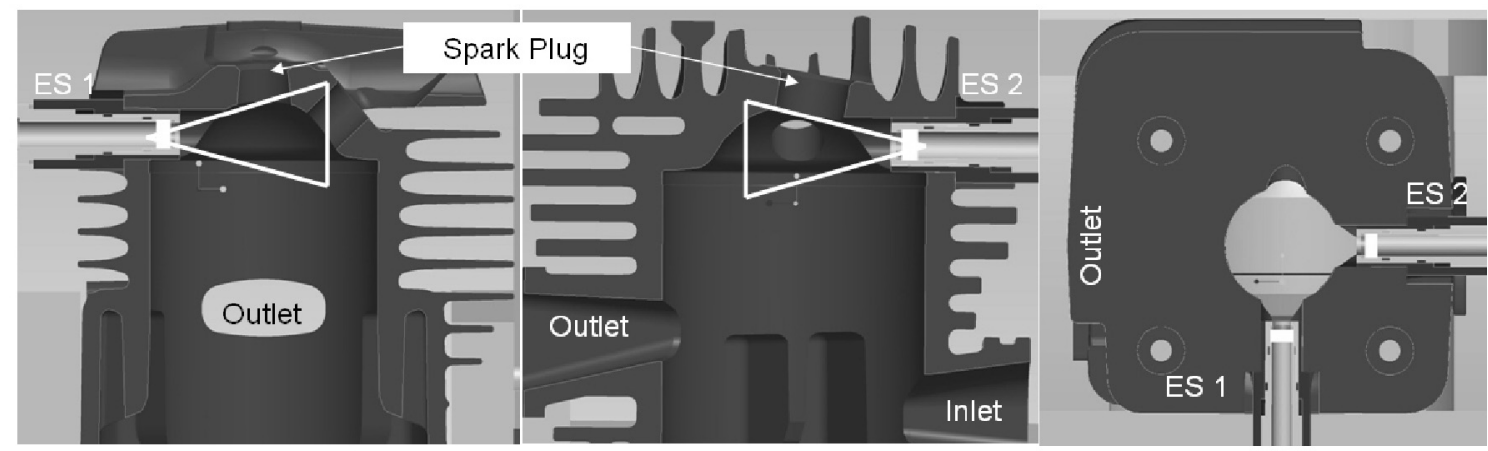
palna, jeżeli jest poddana działaniu wysoki ej temperatury i dużego ciśnienia, co powoduje powstanie takiego zjawiska.

Dodat -

Fig. 11. Observation windows for endoscope 1 and 2 (ES 1, ES 2)

Rys. 11. Okna obserwacyjne endoskopów 1 i 2 (ES 1, ES 2)

kowe zasto- 


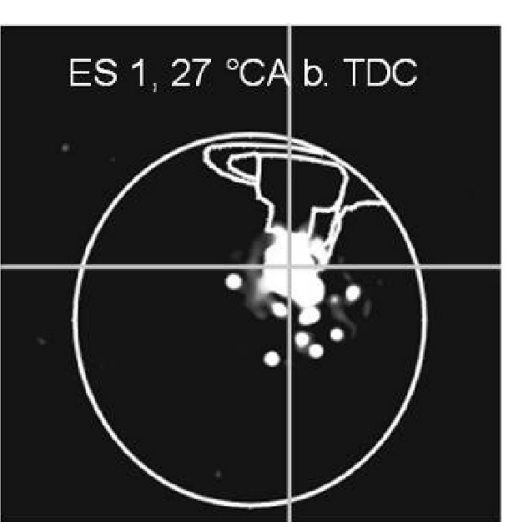

Ignition Point

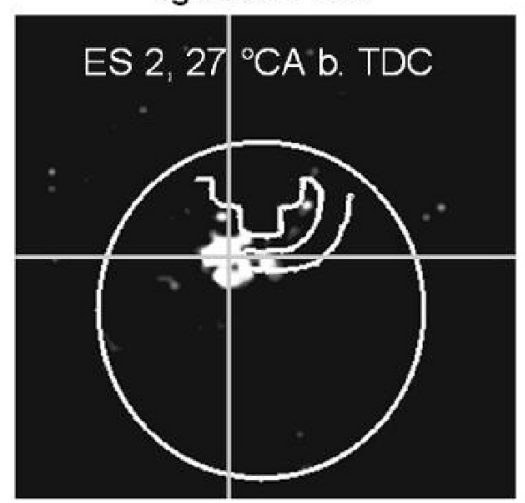

Fig. 12. Full load, speed 9500 rpm

Rys. 12. Petna moc, prędkość obrotowa 9500 obr/min

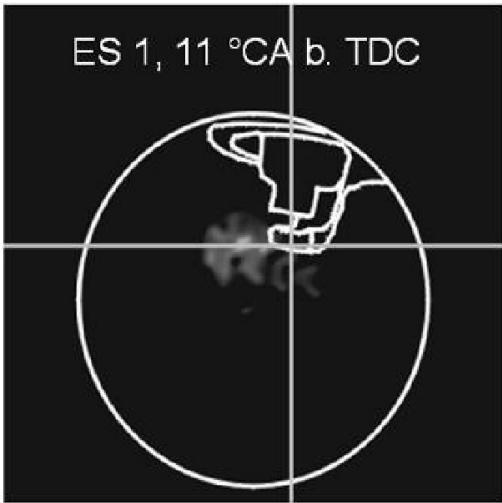

Combustion

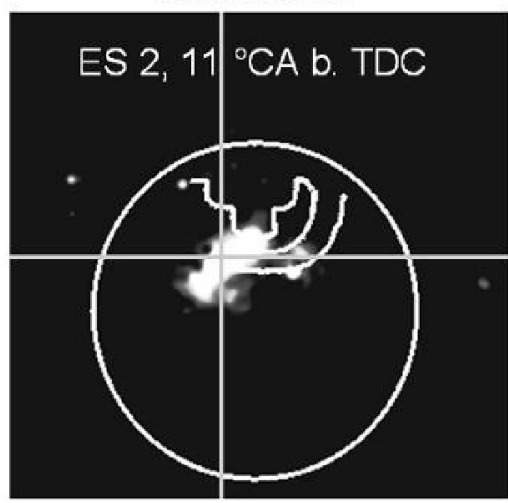
większy jest silnik lub przestrzeń pomiarowa. Innym problemem jest niewystarczająca prędkość filmowania systemów rejestracyjnych w niektórych szczególnych zastosowaniach.

In the observation window of Endoscope 2 the center has hardly moved.

Another method of analysis is shown in Figure 13. These measurements have been performed at part load and an engine speed of $7000 \mathrm{rpm}$. The images on the left side show the point $3{ }^{\circ} \mathrm{CA}$ before ignition, while the pictures on the right side show the point of ignition. It is clear to see that the flame develops before ignition. This auto ignition begins in the hottest spot of the combustion chamber between drive shaft and exhaust. This couldn't be detected by pressure indication, since the point of self ignition is very close to the point of actual ignition. The reason for self ignition is probably the very high rate of residual gas. This mixture is highly inflammable when exposed to high temperature or pressure and therefore causes this phenomenon.

With the aid of this measuring technique it was possible to visualize ignition plasma and combustion. The combustion proceeds with high speed analogical to the scavenging in direction of the exhaust. Furthermore, it was possible to detect auto ignition and to locate the onset of auto ignition. During these measurements it was noticed that with an engine speed of $10,000 \mathrm{rpm}$, the system reached its resolution limit.
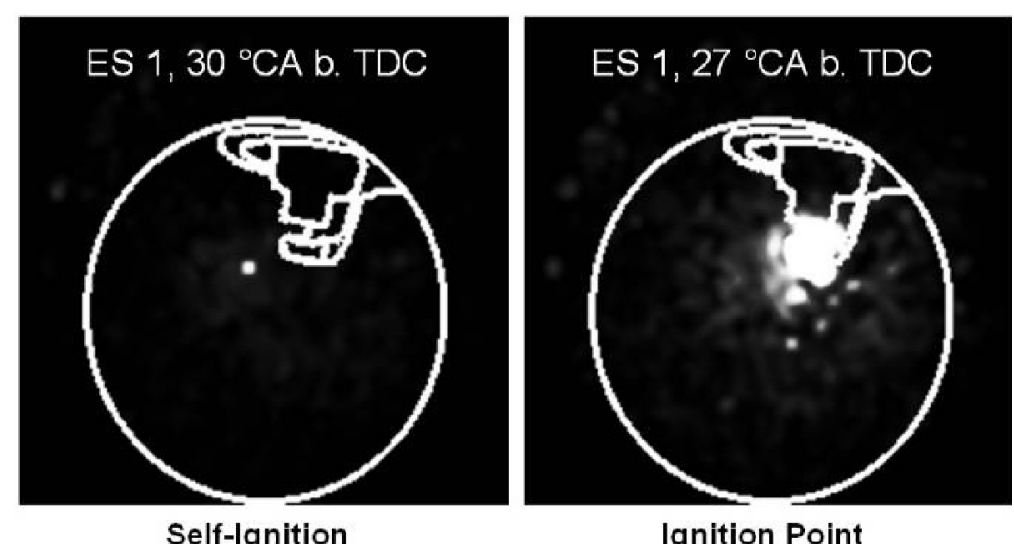

Ignition Point
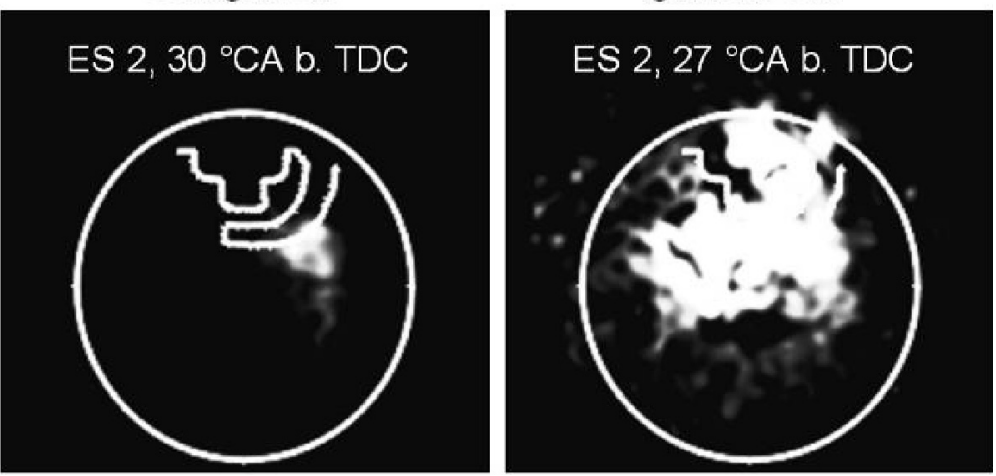

Fig. 13. Part load, speed $7000 \mathrm{rpm}$

Rys. 13. Obciązenie częściowe, prędkość obrotowa 7000 obr/min 


\section{Challenges in high speed imaging}

Besides the numerous advantages and possibilities high speed techniques can offer in engine applications, there are still some challenges the user has to deal with. These barriers can be classified in technical issues and human factors.

On the technical side the biggest difficulty is to get a sufficient amount of light into the measurement volume to ensure good signals of scattered light (e.g. spray propagation). This concerns particularly applications using endoscopic illumination and gets harder all the more the bigger the engines or volumes are. Another point is that the frame rates of high speed systems are sometimes not high enough for the specific application. This is especially the case for the detection of fast processes (e.g. engine knocking) and for applications in high revolution engines (e.g. small twostroke engines).

On the user side there is a latent danger of producing too much data and losing track of the main intention of the investigations. Even if the experiment is well planned the amount of data and images is very high. Therefore automated post-processing and data analysis tools are indispensable. This is especially difficult for unexperienced users. A consolidated view of all these factors indicates that high speed imaging is a very powerful tool but still far away from being a plug an play technique for investigating internal combustion engines.
Występuje to wyraźnie w przypadku rejestracji bardzo szybkich procesów (np. spalania stukowego) i w zastosowaniu do silników szybkoobrotowych (np. małych silników dwusuwowych).

Pod względem czynników ludzkich występuje ukryte niebezpieczeństwo generowania zbyt wielu danych pomiarowych i zagubienia w tym głównego kierunku i intencji badań.

Nawet jeżeli eksperyment jest właściwie zaplanowany, ilość danych i zdjęć jest bardzo duża. Dlatego niezbędne są narzędzia do zautomatyzowanej obróbki danych pomiarowych i analizy wyników. Jest to szczególnie trudne dla niedoświadczonych użytkowników. Całościowe spojrzenie na te uwarunkowania wskazuje, że szybkie filmowanie jest wprawdzie efektywnym narzędziem badawczym, jednak ciągle jest dalekie od techniki typu plug-and-play do badań silników spalinowych.

\section{Nomenclature/skróty i oznaczenia}

HS-PIV - High-Speed Particle Imaging Velocimetry/szybka fotografia wektorowego pola prędkości

CFD - Computed Fluid Dynamics/numeryczna mechanika płynów

Paper reviewed/Artykut recenzowany

\section{Bibliography/Bibliografia}

1. Sauter W., Nauwerck A., Han K.M., Pfeil J., Velji A., Spicher U.: High-Speed Visualisation of Combustion in Modern Gasoline Engines; Second Int. Conf. on Optical and Laser Diagnostics 2005; London, UK.

Prof. Ulrich Spicher, DSc., DEng. - Professor in Karlsruhe Institute of Technology (KIT), Head of Institut für Kolbenmaschinen (IFKM), Germany.

Prof. dr inż. Ulrich Spicher - profesor w Karlsruhe Institute of Technology (KIT), dyrektor Instytutu Silników Tlokowych (IFKM) Uniwersytetu Technicznego w Karlsruhe.

e-mail: ulrich.spicher@kit.edu

Mr. Jürgen Pfeil, MEng. - Group Leader Optical Measurement Techniques at MOT and Institut für Kolbenmaschinen (IFKM), MOT GmbH Karlsruhe, Germany,

Inż. Jürgen Pfeil - pracownik MOT GmbH w Karlsruhe (Niemcy), kierownik Grupy Technik Pomiarów Optycznych w MOT $i$ w Instytucie Silników Tlokowych (IFKM) Uniwersytetu Technicznego w Karlsruhe. e-mail: juergen.pfeil@motweb.de
2. Han K.M., Velji A., Spicher U.: Characterization of spatial Flame Propagation in a DISI Engine by combined Use of Fiber-Optical Visualization Systems and 3D Reconstruction Techniques; 7th Int. Symposium on Internal Combustion Diagnostics 2006, Baden Baden, Germany.

3. Waldenmaier U., Wagner U., et al.: Optical and Numerical Investigation of the Combustion Process in a Single Cylinder Medium Speed Diesel Engine; 26th CIMAC Congress 2010. Bergen, Norway.

4. Gegg T., Kölmel A., Beck K., Spicher U.: Combustion Analysis on Small Two-Stroke SI-Engines for Handheld Power Tools; SAE 2010-32-0062, SAE SETC Conference 2010. Linz, Austria.

5. Gegg T., Kölmel A., Beck K., Spicher U.; Combustion Analysis on Small Two-Stroke SI-Engines for Handheld Power Tools; 9th Int. Symposium on Internal Combustion Diagnostics 2010, Baden Baden, Germany.

Mr. Amin Velji, DEng. - Karlsruhe Institute of Technology (KIT), Managing Director of Institut für Kolbenmaschinen (IFKM), Germany.

Dr inż. Amin Velji-pracownik Karlsruhe Institute of Technology, KIT (Niemcy), dyrektor zaradzajacy w Instytucie Silników Tłokowych (IFKM) Uniwersytetu Technicznego w Karlsruhe. e-mail: amin.velji@kit.edu 